\title{
LOCATIVE CONSTRUCTIONS IN DANGME
}

\author{
Regina Oforiwah CAESAR \\ University of Education, Winneba \\ reginacaesar13@gmail.com
}

Manuscript received 20 May 2020

Manuscript accepted 5 October 2020

*Corresponding author

https://doi.org/10.33736/ils.2283.2020

\begin{abstract}
This paper explores locative constructions in Dangme, a language that belongs to the Kwa family of languages. The paper discusses the components of the basic locative construction in Dangme. It also examines the syntax and semantics of verbs of position and verbs of change of location that function in the basic locative constructions in Dangme. Data were drawn from mainly primary sources from 14 native speakers of Dangme. I demonstrate that postposition and locative nouns mainly express location in Dangme. There are a set of nouns that also function as indicators of location and direction to places. It is to be noted that in locative constructions, the postposition class and the adjunct of location indicate the location of entities in Dangme as in other languages. The postposition class can take the form of a word or a phrase. The phrase is made up of an NP and locative morphemes: $m i$ 'inside', se 'back', no/hiowe 'top', kpcti 'middle', he 'side' nya 'edge of, tue 'edge' and sisi 'under'. The data also revealed that in Dangme, a locative morpheme or phrase can co-occur with a positional verb in a construction to express the position of an entity at a location.
\end{abstract}

Keywords: Dangme locative constructions; positional verbs; change of location verbs; postposition

\section{Introduction}

Every language has a way of indicating a location for an entity. This could be expressed with a word, or a phrase in a clause or a construction. In some languages, existential, locative and possessive predications are handled by verbs, verbal auxiliaries or copulas with tailored existential, locative or possessive meanings such as "be (at)", "live", "have" or "exist". In other languages, some or all of these functions may be coded by verbs of posture or orientation such as "sit", "stand" and "lie", among others (Hellwig, 2003; Newman, 2002). According to Levinson and Meira (2003), a basic locative construction is the prototypical locative construction 
in a given language. The prototypical locative construction is understood as a construction used to locate an easily movable inanimate figure with respect to a ground to which it is attached in response to a "where" question (Levinson \& Wilkins, 2006, p. 15). A locative construction is the construction that occurs in response to a given question of the kind, "where is the $X$ " where $X$ represents the entity the speaker has in mind (Fortis, 2010, p. 1). In Dangme as in other languages, it is common to find out that the locative predications are handled by verbs.

The literature have shown that verbs of position have alternative terms with similar or overlapping semantics in the semantic literature. These include "posture verbs" or "verbs of posture", "positionals" or "verbs of body position", and "verbs of spatial configuration" as posited by researchers (Ameka \& Levinson, 2007, p. 847; Borneto, 1996, pp. 459-505; Levinson \& Wilkins, 2006, pp.15-16; Grinevald, 2006, p. 37; Hellwig, 2003, p. 10; Lemmens \& Perrez, 2010, pp. 315-325; Levin, 1993, p. 255; Levin \& Hovav, 1995, p. 282; Newman, 2002; Rothmayr, 2009, pp. 147-156; Talmy, 1985,2000 a, p. 25; 2007, p. 118 cited in Atintono, 2013, p. 25). According to Atintono (2013, p. 24), the term "positional verbs" is used as a cover term that refers to a class of verbs that semantically code the static assumed body posture or position of animate entities (humans and animals). According to Keegan (2002), posture verbs define a language type in the MPI-based research on basic locative constructions. These verbs can occur in transitive and intransitive constructions.

Newman (2002) uses posture verbs because the contributors focused on human posture while Ameka and Levinson (2007) also use posture and positional verbs as two classes of locative verbs. My use of positional verbs in this paper represents both posture and positional verbs in Dangme. The positional verbs in Dangme as in other Ghanaian languages such as Akan, Ga, Gurene often combine with the postpositions to describe the location of an entity in relation to the ground in a spatial relation.

Dangme is a three-level tone language and it belongs to the Kwa group of Niger-Congo family of languages. It is spoken in two regions of Ghana - Eastern and Greater Accra mainly in South-Eastern Ghana. The people inhabit the coastal area of the Greater Accra Region, east of Accra, and part of the Eastern Region of Ghana. Its closest linguistic neighbours are Ga, Akan and Ewe. Dangme has seven dialects: Ada, Nugo, Kpone, Gbugblaa/Prampram, Osudoku, $S \varepsilon$, and Krobo (Yilo and Manya). There are several small communities east of the Volta Region that trace their origins to Dangmeland; most of these have shifted to Ewe as the language of daily life, but others have not (Dakubu, 1988; Sprigge, 1969 cited in Ameka and Dakubu, 2008, p. 215). Patches of speakers are also found in Togo- Nyetoe and Gatsi who have been mentioned in Christaller (1888), Rapp (1943), Westermann and Bryan (1952).

The purpose of this paper is to discuss locative constructions in four main categories in Dangme; postpositional class, nouns that function to indicate location and direction to places, positional verbs and verbs of change of location that function in the basic locative constructions in Dangme. 


\section{Purpose of study}

The aim of this paper is to discuss the formation of locative constructions in Dangme in the following ways:

1) to discuss the simple locative constructions in Dangme;

2) to examine the syntax and the semantics of positional verbs that co-occur with locative elements in Dangme; and

3) to discuss verbs of change of location in basic locative constructions in Dangme.

The findings of the study will add to the relatively limited literature on the grammar of Dangme and also serve as a basis for further research into other areas of the syntax and semantics of Dangme. It is also hoped that the findings of this study will add to the literature on locative constructions universally.

\section{Methodology}

The data were collected from 14 native speakers of Dangme. Two from each dialect group in 2019. The primary data were collected through unstructured interviews, overheard spontaneous speech, picture and positional posture discussions, and from texts. Photographs showing various locations of items (Appendix A and B) were also presented for native speakers to describe. The responses of informants were recorded on audio tape and later transcribed. As a native speaker of Dangme, I also provided some of the data for this study. The data elicited and those which were provided by me were however, cross-checked by other native speakers of Dangme.

\section{Locative constructions in Dangme}

Locative expressions refer to statements that speakers provide as natural responses to questions demanding the location or whereabouts of people and objects or spontaneous statements that speakers make to draw the attention of the addressee to the location of entities in a discourse context with or without a question posed (Atintono, 2013; Fortis, 2010). Levinson and Wilkins (2006, pp. 1-2) have indicated that basic locative constructions are the expressions that are commonly used in response to a where-question in delivering the basic locative function. Thus, these expressions are the answers one gives to a questioner when a question is posed about the location of an object. In the field of linguistics, a lot of work (Ameka, Witte, \& Wilkins, 1999; Bobuafor, 2013; Dorvlo, 2008; Levinson \& Wilkins, 2006) has been done in this area.

The simple locative construction in Dangme consists of adpositions. According to Van Valin Jr. \& LaPola (1997, p. 52), adpositions consist of prepositions and postpositions (see also Ameka, 1995; Boadi, 1992; Dovlo, 2008, p. 117; Tallerman, 2014, p. 45). Ameka (1995, p. 145) asserts that some African languages such as Hausa and Maa have both verb-like and noun-like prepositions. In Kwa languages such as Akan, Ewe and Ga, however, the verbal adpositional elements tend to be prepositions and the nominal adpositions tend to be postpositions. The 
prepositional phrase in English consists of a preposition which is followed by a prepositional complement normally a noun phrase or a wh-clause or a $V$-ing clause (Quirk \& Greenbaum, 1973). Quirk and Greenbaum (1973, p. 143) posit further that "a preposition expresses the relationship between two entities, one being that it is represented by the prepositional complement". According to Dakubu (1987, p. 83), there is often a relationship between the NP and the VP required in a postposition in Dangme. That is a word is included in the NP that serves in some sense to "locate" the NP in question. Consider the examples of adpositional phrases in italics in (1a-c).

1. (a) The boy is in the classroom.

(b) The stick is on the table.

(c) The dress is under the bed.

From the English examples in (1a-c), we observe that the preposition in, on, under occur at the initial position of the prepositional phrases. Thus, this makes English a prepositional language. By contrast, Dangme is a postpositional language because the adposition occurs usually after the noun phrase or the content question which is referred to as Wh-clause in English, it follows. The locative construction in Dangme is made up of a verb, $n g \varepsilon$ "is", a postpositional phrase which consists of a noun phrase and a postposition. The postposition occurs after the NP (the object), to which the speaker draws the addressee's attention to. The NP is what Aarts (2001, p. 44) refers to as prepositional object or complement in English. Consider samples of locative constructions in (2a-c) that attest to the claim that Dangme is one of the postpositional languages. Postpositions form a closed class of grammatical class in Dangme as in some other Ghanaian languages.

2. (a) Gbé J ngè tsō ว sìsì.

Dog DEF at tree DEF under

"The dog is under the tree."

(LOCP1)

(b) Jíjé à ngè ní J yèé ngé?

QP 3PL at food DEF eat.PROG at?

"Where are they eating the food?"

(c) À ngè ní J yèé ngé kpókú J nyà.

They are food DEF eat.PROG at entrance DEF edge

"They are eating the food at the edge of the entrance."

(LOCP2)

(d) Jíjé wà màá nà lò $\supset$ èkō ngć?

OP IP FUT see fish DEF some at

"Where will we get some of the fish to buy?"

(e) Nyغ̇ màá nà èkō ngè jùà à mì.

2 PL FUT get some at market DEF inside

"You will get some in the market." 
We observe in example (2a) that the postposition sisì "under" in the adpositional phrase occurrs clause finally. The postposition nyà "edge of" in (2c) points to the position of the postpositional object, kpókú $\supset$ "the entrance". Similarly, construction (2e) is the response to the question in (2d). Ngغ jùà à mì "in the market" is the postpositional phrase indicating the location where the object $/ o$ "fish/meat" could be bought from.

3. (a) Bùć bágì ว ngè dákà à mì. Bùć.POSS bag DEF COP box DEF inside "Bùc's bag is in the box."

(b) Tsıólo` ว’ ngè pà à nyà.

Teacher DEF at river DEF mouth.

"The teacher is at the river bank."

(c) Àtí jo ngè tsū o yī no.

Cat DEF at room DEF head top.

"The cat is on top of the roof."

(LOCP5)

(d) Àdétà ngè sùkúú tsū J $^{\text {nè. }}$

Àdétà at school building DEF side

"Àdétà is by the school building."

(e) Solèmì tsū j́ ngè mà à kpètí.

Church building DEF at town DEF middle

"The chapel is at the centre of the town."

(f) Kóวpòó ว` ngغ̀ nyū ว` hé.

Cup DEF at water DEF face

"The cup is on the surface of the water."

(LOCP6)

(g) Tòkòtá à ngè òkploว $\supset$ sìsì.

Foot wear DEF at table DEF under

"The foot wear is under the table."

(LOCP7)

(h) Safie J ngè tànki $\supset$ tūé.

Key DEF at tank DEF edge

"The key is at the edge of the tank."

In (3a-h), the verb $n g \dot{\varepsilon}$ "at" is a be-located verb that takes arguments that express the location of the object. From the data available, $n g \varepsilon \dot{\varepsilon}$ is used in reference to the position or the location of an entity which can be animate (human and animal) and inanimate. $N g \varepsilon$ also has the meaning "be.at" or can be interpreted as $\mathrm{X}$, the subject, is at a certain location as discussed in positional verbs and verbs of change of location in section 3 and 4 of this paper. In (3a), Bùć bágì $\supset$ is the subject of the clause. "Bùć's bag" is at a certain location dákà à mì "in the box" mì "inside" is the 
portion of the box where the subject, Bùć bágì ग, "Bùč's bag" can be found or

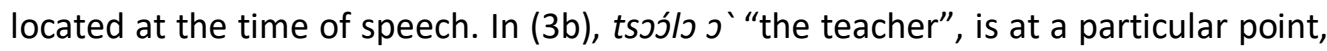
nyà "edge of" of pà à "the river". In (3c), tsū כ yī no "at the top of the building" is where the subject, àtí $j$ "the cat" is situated at the time of speech. Àdétà in (3d) can be located by hè "side of" the object of the phrase, sùkúú tsū ว "the school building". In (3e), solèmì tsū $j$ "the chapel" is situated at a location, kpغ̇tí "middle" of mà à "the town". In (3f-h), kóopòó J" "the cup" is at the surface, hé of nyū o "the water", tòkòtá à "foot wear" is at a point, sì̀ "under" of the object òkploว o "the table" and safie $\supset$ "the key" is at a location, tànki $\supset$ tūé "at the edge of the tank" respectively.

I discuss locative pronouns that point to places in (4a-5b).

4. (a) Wà bā híć o līngmī né ว’.

$1 \mathrm{PL}$ come.AOR here recently this

"We came here recently."

(b) Sūkúú bímè ngè hí o.

school children at here

"School children are here."

5. (a) À hō lējés’ yà píว’.

3PL go there PRT now.

"They have just gone there."

(b) Tっ ว` ngè lējé o kpàmìsá.

Bottle DEF at there still.

"The bottle is still there."

In (4a) and (4b), hí $\supset$ "here" is the object of the clause that points to a location. Híc o "here" in (4a) is followed by an adverbial phrase, līngmī né ว" "recently". In (5a), the locative NP lējé ว" "there" is preposed in the construction. That is, it has occurred in between the verb phrase hō ...yà "have gone". Lejjé ว" "there" in (5b) has occurred after the verb of be-located ngkे as in (4a). According to Van Staden (2007), the ground space indicating verbs are classified into two classes; those encoding location "be prox/ dist/ media-Generic/ down/ up/ seaward/ landward); those encoding direction (same semantic distinction). When an NP with postposition is an adjunct filling the role of an adverbial phrase, it clearly indicates direction or location (Dakubu, 1987:84). Dangme has a set of nouns that function to indicate location and direction to the cardinal points. Consider examples (6a-d).

6. (a) Yo' ว’ jè bōká blo kغ̀ ma`.

Woman DEF leave east way AUX come.

"The woman is coming from the eastward."

(b) Kóshīo né fià à jè àné blo.

Wind that blow PRT leave westward way.

"The wind that blew was from the west." 
(c) Élóplèé j’ jè wò mì blo. Airplane DEF leave sea inside way. "The airplane appeared from the southern part."

(d) Sàlífù jè Ghana mà à è yìí màjè. Sàlífù leave Ghana country DEF 3SG.POSS top area "Sàlífù comes from the northern part of Ghana."

The locative nouns bōká "east", ànć "west" and the descriptive nouns, wò mì blo" south" and yìtí màjè "north" locates the cardinal points in Dangme.

\section{Positional verbs of Dangme}

Positional verbs are those verbs which, in combination with one of several locational preverbs, may appear in the basic construction that functions as an answer to a "where" question, the so called basic locative construction (Kutscher \& Genc, 2007). According to Ameka and Levinson (2007), in addition to the prepositions and postpositions used in expressing locative statements, there are many more languages that have a set of alternative verbs or verbal affixes such as verb of "sitting", "standing" and "lying". The verbs, "sit", "stand" and "hang", etc. are classified according to which verbs they take in both existential and locative statements (Levinson \& Wilkins, 2006, p. 173). The use of postural verbs to code basic locative functions on Goemai, dates back to the 2003 (Ameka \& Levinson, 2007; Hellwig, 2003).

Dangme positional verbs express the posture of an animate (human or animal) in a construction. The posture can be dàa si "standing", hií si "sitting", hwoכ sí "lying down", kpláà sí "hanging" or "dangling", so sí "squatting", kplãã sí "kneeling down" and kpásà sí "leaning". These states, according to Keegan (2002), are typically entered into through relatively brief movements. They code a static position of animate and inanimate entities. Posture verbs according to Fortis (2010, p. 4) and Atintono (2013, p. 183), constitute a small set, often with an anthropomorphic source such as "sit", "stand", "lie" though not exclusively "hang" which often have causative counterparts. They have a "sortal" character, i.e. they classify their subject nominal concepts by semantic criteria (Ameka \& Levinson, 2007 , p. 859). Position verbs indicate the positions that verbs assume (move to) and the positions such verbs currently occupied (Atintono, 2013). It is to be noted that these verbs strictly mean "come to be in X position" where " $X$ " can be "sitting", "lying", "standing", "leaning against" or "hanging". That is, to be: at---, on---, in---, by--- position and become "sitting", "lying", "standing", "leaning against" or "hanging" that are used in expressing locative function (Ameka, 1999; Dakubu \& Ford, 1988). Dangme positional verbs denote the posture of animate and inanimate entities and have causative meaning. They are in the form of phrasal verbs.

In Dangme as in English, phrasal verbs are made of two parts: a base verb and a word that is either a postposition or an adverb particle. These phrasal verbs occur as a $V+$ Particle. It is not always possible to guess the meaning of a phrasal 
verb from the individual morphemes that constitute the word as indicated above. They occur as postpositions. These postpositions denote change of positions. They include:

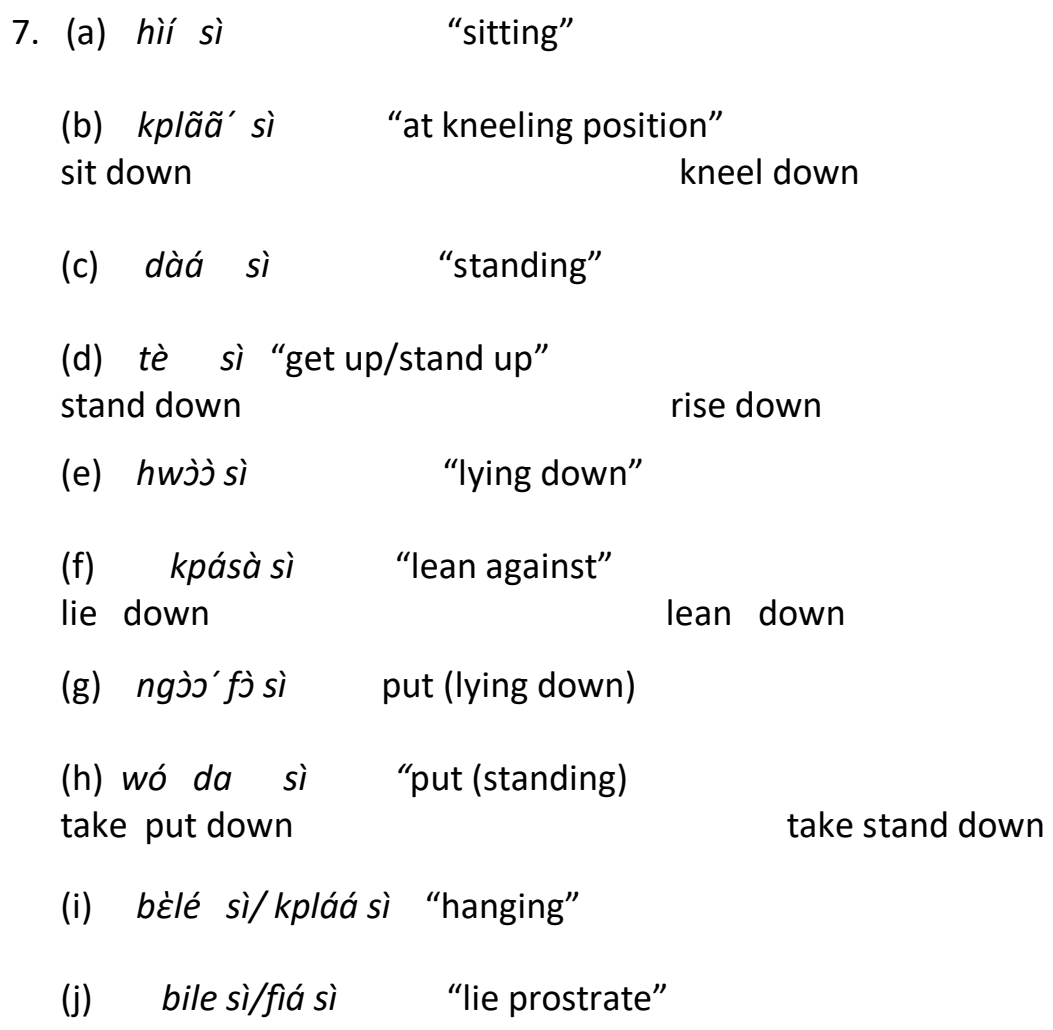

hang down lie down straight

Dàa si "standing" is a posture verb that indicates that the reference is supported from the ground and points vertically upwards. Dàa sì "standing", applies both to animate and inanimate entities. For instance: Tawiah dàa sì. "Tawiah, is at a standing position" (on or in or by or under something, or at a location). Hií sì "sitting" is used to denote a stable position for animate and inanimate entities on the surface of an object. For example, Gad hii sì. "Gad is at a sitting position" (on or in or by or under something or at a location).

kpláà sì "hanging" or "dangling" is used to refer to an object tied to one end upwards and pulling down vertically from the point of the attachment, that is, a "hang" verb describes an entity suspending on the surface of the ground as in kpà à kpláá si "the rope is hanging" (on or in or by or under something or against something, from a direction or at a location). Soj 'si "squatting" refers to a postural shape. It is a verb used to denote entities that are at the lowering position of the body with reference to folding of the legs at the knee level. Nàkí soว sì. "Nàkí is at a squatting position" (on or in something, or at a location).

Kpásà sì "lean against" is used for entities that are positioned diagonally with their tips against the edge of the upper part of the entity receiving support as exemplified in Tsàátsé kpásà sì ngé gli $\supset$ he. "Father is leaning against the wall". Hwวכ' sì "lie down" is a positional verb mostly predicating the posture of an animate 
entity on a ground surface. The verb, $f \jmath^{\prime}$ ' si "lie down" is, however, used for inanimate entities to express the same meaning as hwo 'sì. These verbs of position can occur with postpositions to indicate the location of the postures expressed by the verbs as exemplified in (7-8).

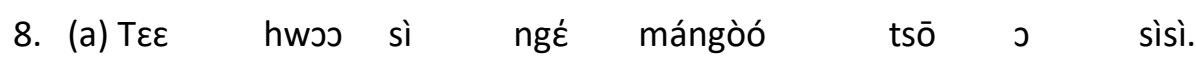
Teye lying down at mango tree DEF under "Teye is lying down under the mango tree."

(b) Tsō o fơ' sì ngé blo ว’ mì. Tree DEF lie down at path DEF inside

"The stick is lying in the middle of the path."

Hwวว' si and foว' sì express the posture of the entities at a location, ngé mángòó tsō o sisi, "under the mango tree" and ngé blo ว mi, "in the middle of the path" in (7a-b). The objects of the postpositional phrases in (8a \& b), mángòo tsō $\supset$ " "the mango tree" and b/د د "the path" are preposed. That is the postpositions ngé sì̀̀ "is under" and ngé mi "is inside" have become ngé... sisì "at ... under" and ngé... $m i$ "at...inside". The positional verbs in Dangme often combine with postpositional phrases to describe the location of an entity in relation to a ground in a spatial relation. The entity designates the object that is located (Talmy, 1985, pp. 60-61; 2000a, pp. 311-315, 2007, p. 70; Levinson, 1992, p. 11). The ground acts as the reference point or the place where the figure is located (Talmy, 2000a, p. 312; 2000b, p. 25). Consider these examples (9):

9. (a) Nyumu j’ hì́ sì ngé $s \varepsilon^{\prime} \jmath^{\prime}$ mì. Man DEF sit.PROG down be.at chair DEF inside.(PPOS1) "The man is sitting in the chair."

(b) Bímwวyo' j’ hwo'ว’ sì nge' sà à no. Baby DEF lie.PROG down be.at mat DEF on. "The baby is lying on the mat."

(PPOS2)

(c) Nàkí kpláá sì nge' zugba'.

Nàkí kneel.PROG down be.at ground.

"Nàkí is at a kneeling position on the ground."

(d) Siàde' soo' sì ngé àgbo' j’ nyà.

Siàde' squat.PROG down be.at gate DEF mouth.

"Siàde' is at a squatting position at the entrance of the gate." (PPOS4)

(e) Àdò kpásà sì ngé glì j’ hē.

Àdò lean.PERF down be.at wall DEF side.

"Àdò has leaned against the wall."

(PPOS5) 
The positional verbs in the constructions in (9a-e) express stative locative relations. The entities that have assumed the varied positions and postures in sentences (9a-e) are represented by the nouns in the subject positions: Nyumu' 0 ' "the man" in (9a), bímwวyo 'o "the baby" in (9b), Nàkí "a personal name" in (9c), Siàde "a personal name" in (8d) and Àdò "a personal name". The subject NPs are human nouns whose body positions are described by the posture predicates hii si "be sitting", hwo ' 'sì "be lying", kpláá sì, "be kneeling" soว 'sì "be squatting" and

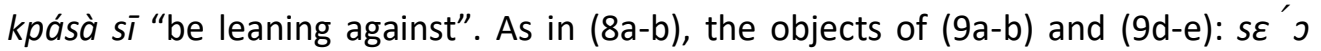
"the chair", sà à "the mat", àgbo ' $\supset$ " "the gate" and glì o "the wall" - have occurred in between the locative markers: $n g \varepsilon^{\prime}$ 'mi "is inside", $n g \varepsilon$ ' $n \bar{\nu}^{-}$"is on top", nge 'nyà "at the entrance" and $n g \varepsilon^{\prime}$ ' $h \bar{e}$ "by the side". (9c) however, points to a location represented by zügba "ground".

10. (a) Ngmòngmlòkí hì nyùmù $\supset$ sì ngé tsū $\supset$ sē. Ngmòngmlòkí sit man DEF down at house DEF POSTPOS 'Ngmòngmlòkí put the man at a sitting position at the back of the house.'

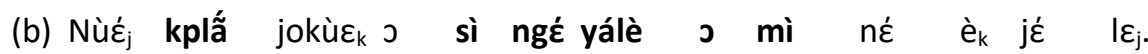
SG.OBJ

Nù́ $\dot{\varepsilon}_{j}$ kneel child DEF down at yard DEF inside when 35 insult

'Nù $\varepsilon_{j}$ put the child to a kneeling position in the yard when he/she insulted him.'

In (10a), Ngmòngmlòkí caused nyùmù o "the man" to be at a sitting position at a location, ngé $t s \bar{u} \supset$ se "at the back of the house" . In (10b), the subject, Nù $\varepsilon_{j}$, moved the object jokù $\varepsilon_{k} \supset$ "the child" from an unspecified position at time one $\left(\mathrm{t}_{1}\right)$ to $k p l \tilde{a}^{\prime}$ sì "a kneeling position" at a subsequent time two $\left(\mathrm{t}_{2}\right)$ at a location, ngé yálè o mì "in the yard" for insulting him. In the syntax, this form of verbs involves a separate rule which shifts complements one step to the left of the main verb in a transitive construction. For instance, hì si "sit down", kplấ sì "kneel down" with the objects nyùmù $\supset$ "the man" and jokù $\varepsilon_{k} \supset$ "the child" in (10a) and (10b) respectively, will become hì nyùmù $\supset$ sì "sit the man down" and kplấ jokù $\varepsilon_{k} \supset$ sì "put the child at a kneeling position". Also in (11), a verb like kpásà sì "lean against" plus an object pàmplòó "bamboo" will become kpásà pàmplòó sì "lean the bamboo against something" as in the transitive example in (11a). Thus, kpásà sì + object $\rightarrow$ kpásà + object + si.

Position verbs can be expressed transitively and intransitively in Dangme as in other languages. The transitive verbs of change of position are causative. They are verbs of motion that indicate the position in which the direct object is placed. Thus, position verbs express the meaning that an entity is causing another entity (the object) to be placed in a certain position with respect to the ground which can be "be in a position" of sitting, standing, lying, hanging, etc. That is the stative locative constructions are used to code "be in a position". 


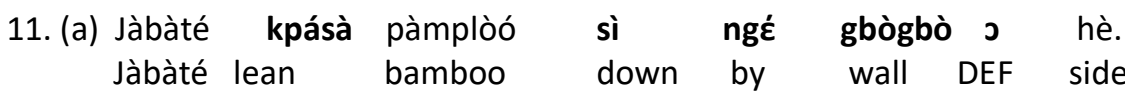
'Jàbàté lean bamboo against a wall.'

(PPOS6)

(b) Pàmplòó kpásà sì ngé gbògbò hè.

Bamboo lean down by wall side

'A bamboo is leaned against a wall.'

12. (a) Kúmá b̀clé kpà à sì ngé tsō j̀ nò.

Kúmá hang.PERF rope DEF down by tree.POSS DEF top

'Kúmá hanged the rope to the tree.'

(b) Kpà à b̀clé sì ngé tsō jò nò.

rope DEF hang.IPFT down by tree.POSSDEF to

'The rope hangs on the tree.'

Thus, in (11a) the direct object, pàmplòo "bamboo" moved to be at a leaning position at a location, gbògbò hè "by the wall" by Jabate. The intransitive verbs distinguish between verbs of motion, which indicate the position where the subject currently occupies. Thus, "come to be in a standing position" only if the previous position is lying or sitting and from a standing position in one place to another standing position. The original position of the theme is not expressed, but, the new position is denoted by postposition. In the intransitive example in (11b), the new position of the subject, pàmplòo is indicated by the position kpásà sì "lean down" at a location, gbògbò hè "by the wall". In (11b), a resultative state of the new position pàmplòo "bamboo" has assumed, is presented. Thus, the subject for the new position is covert or not expressed.

The example in (12a) indicates a change of position of the object kpà $a$ "the rope", from a lower level to a hanging position. This change of position came about as a result of an action initiated by the subject, Kúmá. The phrasal verb, b̀clé sì "hang down" means "come to be in a hanging position" ngé tsō $j$ nj "on the tree" is the location goal of the object. The phrasal verb, b̀clé sì "hang down" has become discontinuous in the transitive sentence of (12a); the object kpà à "the rope" appears in between the verb b̌clé "hang" and its postposition sì "down". Hang is used to indicate that the object, kpà à "the rope" is supported from above. This means that the rope is attached only to one point of the tree. The result of the action of the subject, Kúmá, is the current position the object kpà à has assumed. In other words, $X$ brought it about that $Y$ had to change position and became placed up high at location two, on the tree. In (12b) on the other hand, the object, kpà à "the rope" fills in the subject position since the subject position of the clause was vacant. The verb b̌lé sì "hang down" is not discontinuous as in (12a) simply because, the use of b̌lé sì in (12b) does not require a complement as in (12a). Sentence (12a) implies that (x), Kúmá did something that brought it about that (y), kpà à "the rope" has come to be at a hanging position at a location on the tree. The semantics of sentence (12b) is that ( $y$ ) has come to be in a hanging position at a location. 
Consider other verbs of change of position in (13a-14b).

13. (a) Dèdék hwòj̀ è $e_{k}$ bí j̀ sì ngé tsù j̀ mì. Dèdé lay.PERF 3SG.POSS child. DEF down in room DEF inside "Dèdé put her child to bed in the room."

(b) Dèdé bí j̀ hwò̀̀ sì ngé tsù j̀ mì. Dèdé.POSS child. DEF lie down in room DEF inside "Dèdé's child is lying in the room."

14. (a) Amúzù kpásà àtsilé j̀ sì ngé gbògbò j̀ hè. Amúzù lean ladder DEF against at wall DEF side "Amúzù leaned the ladder against the wall. "Amúzù caused the ladder to be by the wall."

(b) Àtsilé j̀ kpásà sì ngé gbògbò j̀ hè. ladder DEF lean against at wall DEF side "The ladder leans against the wall." (PPOS7)

In (13a), Dèdé and è bí j̀ "her child" are the NPs of the sentence. Hwj̀̀ sì

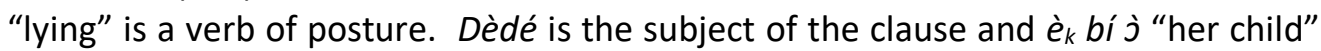
is the object-undergoer of the action of move designated by hwj̀ sì "be in a lying position". As in (13a), the phrasal verb of (13a) is also discontinuous with its object intervening. This action of change of position initiated by the subject is expressed by the verb phrase hwj̀ sì "lying down" which co-occurs with the postpositional phrase, ngé tsù j mi "in the room". The postpositional phrase indicates the location where Dèdé bí j "Dede's child" currently lies. The verb, hwj̀ sì "lying down" implies that Dèdé bi $j$ is being supported from the ground. The result of the action of the subject, Dèdé, is the current position the object, è bí $\dot{j}$, has assumed at a location. Clause (13b) as in (12b) has the object of hwò̀ sì "be in a lying position" as the subject of the intransitive clause. By contrast, the verb phrase, hwj̀ sì is not discontinuous as in (13b). The semantics of clause (13a) is that (x), Dèdé, brought it about that è bi $j$ "her child" became at a lying position in a room. While clause (13b) means that $(y)$ has come to be in a lying position in a room.

In (14a), Amúzù is the subject of change of position and àtsilé $j$ "the ladder" is the complement of the verb phrase kpásà sì "lean against". Àtsile $j$ "the ladder" is the object of the clause which change of position is attributed to Amúzù, the subject. The new position of the ladder has been indicated by the predicate, kpásà sì "lean against" at a location, ngé gbògbò j̀ hè "by the wall". Kpásà sì in (14a) is discontinuous as in (12a \& 13a). "Lean against" is used to indicate that the object, àtsile $j$ "the ladder", is supported from the side of the wall. This means that the ladder is attached to one side of the wall. The result of the action of Amúzù, is the current position the object, àtsile $\dot{j}$, has occupied. In other words, $X$ causes $Y$ to change position at time one $\left(t_{1}\right)$ and become placed by the side of the wall at a subsequent time two $\left(\mathrm{t}_{2}\right)$. Ng ǵ gbògbò j hè "by the wall" is an adjunct of location. Example (14a) denotes that (x), Amúzù did something that resulted in (y), àtsilé coming to be at a position of leaning at a location, ng ́x gbògbò j̀ hè "by the wall". 
The semantics of sentence (14b) is that (y) has come to be in a leaning position by the wall.

\section{Verbs of change of location}

In the previous section, I dealt with phrasal verbs of change of position. In this section, I discuss lexical causative verbs that denote a change of location in an entity at locations expressed by the postposition class or adjunct of location. They express the notion of "be.on", "be.at", "be.in", "be.by" and "hang" (see Essegbey as cited in Ameka \& Levinson, 2007; Ameka, de Witte, \& Wilkins, 1999).

Positional and locational verbs employ almost the same postpositions to express change of position or location, but in change of position, the postpositional phrase focusses on the positioning of the object. Change of location however, has more to do with a place. Some postpositions and adverbs especially of place used to denote a change of location in Dangme include:

15. hè

mì

sis̀̀

hé mì

"side"
"in/inside"
"down/downstairs"
"in front of"

"in front of"

zùgbá nò "(on the)ground"
wē mì "in the house"
$\quad$ hé "place"

These postpositions co-occur with lexical verbs to denote the change of location in objects. A verb of this nature requires an actor/causer (initiator of the process of change of location), object-patient-theme and a location where the patient-theme is deposited as expressed by the locative complement. In addition, the lexical verb with an adverb of place can also be used to express location in Dangme. Verbs made complete by postpositional phrases to illustrate change of location include:

$\begin{array}{llcc}\text { 16. fá } & \text { "order" } & p l \varepsilon ́ / k p a ́ ~ & \text { "pour" } \\ k \dot{\varepsilon} & \text { "take" } & f j & \text { "put" } \\ \text { tsì nyà } & \text { "detain" } & \text { bú nyà } & \text { "cover" }\end{array}$

These verbs can be used transitively and intransitively. I now examine transitive sentences that express cause-and-effect relation only in locative constructions in Dangme. Consider sentences (17-23):

17. Dòósì fá Àkùàfò ${ }_{j}$ ké é $e_{j}$ yá hì tsù j̀ sìsì.

Dòósì order Àkùàfò that $3 \mathrm{SG}$ go sit vroom DEF down

"Dòósì ordered Àkùàfò to sit at the ground floor of the building."

18. Bàtsá plé/kpá nyù j̀ kè pùé zùgbà à nò.

Bàtsá pour water DEF AUX pour ground.OBLQDEF on

"Bàtsá poured the water on to the ground."

19. Kòjólj̀ j̀ wò jùl’̀ j̀ tsu mì.

Judge DEF put thief DEF prison inside.OBLQ

"The judge put the thief into prison cell." 
In (17), Dòósì is the subject and Àkùàfò is the grammatical object of the clause. The verb of the predicate, yá hì "go sit" is made complete in causation with the locative phrase tsù $\dot{\partial}$ sisì "under the tree". Tsù j̀ sis̀̀ is an adverb of place that indicates the new location of Àkùàfò $j_{j}$. This means that Dòósì causes Àkùàfò to change location and be at the ground floor of the building. Thus, the cause is in fá "order". This implies that but for the order from Dòosì at an earlier time one $\left(\mathrm{t}_{1}\right)$, Àkùàfò ${ }_{j}$ would not have been sitting at that new location tsù j̀ sìsi at that particular time which is at a subsequent time two $\left(\mathrm{t}_{2}\right)$.

The verb plé/kpá "pour" takes two NPs: Bàtsá is the subject and nyù $j$ "the water" is the complement of the action of plé/kpá. Nyù $j$ "the water" is the object whose position has been changed. It is said that Batsa, the subject is responsible for the new location of the object nyù $j$. This change in location has been expressed by the discontinuous VP in the predicate, plé ... pùé "poured on to". On the floor, zùgbà $\grave{a} n \grave{j}$ is therefore the new location of the theme, nyù. This means that the water would not have been at that new location zùgbà à nj̀ "on the floor" at that subsequent time $\left(t_{2}\right)$ if Batsa has not, at an earlier time $\left(t_{1}\right)$, caused it to happen.

Sentence (19) has Kòjólj j "the judge" as the subject and jùlj̀ $j$ "the thief" is the theme whose position is assigned by the verb wò "put". The subject, kòjólj j "the judge" is construed as being responsible for the action of change of location from an unexpressed location of the theme, jùlj $j$ "the thief" into a prison's cells. This action of the subject is expressed by the lexical causative verb wò "put" and the postpositional phrase, tsu mi "in cells" at $\left(\mathrm{t}_{2}\right)$. The object would not have been at his current location tsu mì "in to prison cell", if the subject, kòjólj j̀ has not, at an earlier time $\left(t_{1}\right)$, caused him to move from the unexpressed position.

I now examine another group of verbs of location constructions in (20-22) which become discontinuous as in the transitive constructions discussed in (11a, 12a \&13a).

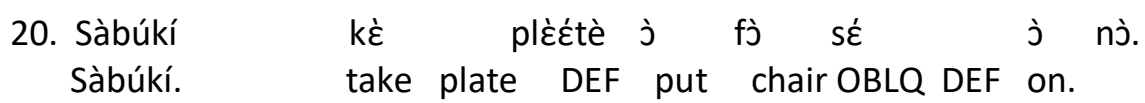

"Sàbúkí put the plate on the chair."

There are two participants in (20) as in (11a), (12a), (13a), (14) and (17). These are Sàbúkí and pléźtè j "the plate". Sàbúkí is the subject for the phrasal verb $k \dot{\varepsilon} f \dot{j}$ "take put". The postpositional phrase sć $\dot{\jmath} n \dot{j}$ "on the chair" indicates the new location of the theme. The subject is responsible for the change of location of the object, pléźtè $j$ "the plate". This change of position would not have happened at $\left(t_{2}\right)$ if Sàbúki has not initiated an action which moves the object at an earlier time $\left(\mathrm{t}_{1}\right)$. The sentence denotes that $(\mathrm{x})$, Sàbúkí in (17) changed the location of (y), pléźtè "plate" by placing it not at its original point but on the chair, sé $\dot{j}$ nj.

$\begin{array}{lllll}\text { 21. Yàò } & \mathbf{k} \text { s̀ } & \text { siká à fò } & \text { òkplò } & \text { j̀ nò. } \\ \text { Yaw } & \text { take } & \text { money DEF put } & \text { table } & \text { DEF top } \\ \text { "Yaw put the money on top of the table." } & & \end{array}$


In (21), Yàò, the subject of the clause changed the position of siká à "the money" by moving it from an unexpressed location to on to the table. Yào is therefore the agent of $k \dot{\varepsilon} f \dot{j}$ "put" and siká a "the money" is the undergoer of the action initiated by Yàò. The original location of the siká á "the money" in sentence (21), has been changed by the action of the subject. Yào's action is expressed by the phrasal verb

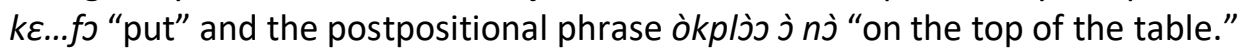

It is observed that sentences (19-21) make use of the lexical verb wò and the phrasal verb kغ่ fj̀ both translating as "put" and tsì nyà "detain" in (21) and (22) to express cause which move objects from one location to another. The structure of

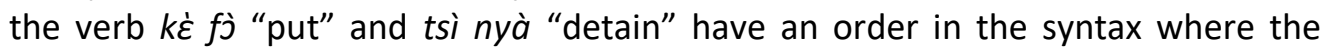
object is moved in between the two locative verbs (pre-posed) as discussed earlier in this paper. Each of the actions expressed are triggered off by subjects whose earlier actions resulted in relocating the objects.

22. Dókità à tsì Màámlé nyà ngé tsámì hé j̀.

Doctor DEF detain Màámlé body-part at hospital.OBLQ place DEF "The doctor detained Màámlé at the hospital."

Change of location verbs also expresses various degrees in direct and indirect causative. These verbs typically express movement, manner and path or goal. Path or goal information is expressed by locative nouns. The kind of change this type of verbs denotes is physical. Verbs of change of location in Dangme can be in the form of phrasal verbs. These include:

23. (a) mà fo kì jè "run race move leave"

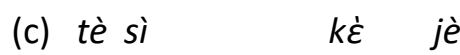
"get up/wake up move leave"

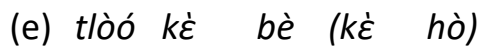
"carry move pass (move go")

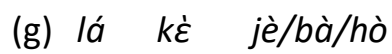
"sing move leave/come/go"

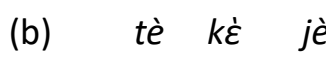
"fly move leave"

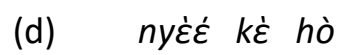
"walk move go"

(f) wo zí "vanish"

(h) jè $\quad k \dot{\varepsilon} \quad b \grave{a} / y \grave{a}$ "leave move come/go"

Consider the basic sentences and causative sentences that express a change of location in Dangme. The basic sentences are non-causative.

24. (a) Dèdé mà fo k̇̀ jè Sékésùá. Dèdé run.AOR race move away from Sékésùá. "Dèdé ran away from Sékésùá."

(b) Tsj̀ólj̀ o' há Dèdé mà fo kè jè Sékésùá. Teacher DET make.AOR Dèdé run race move from Sékésùá. "The teacher caused Dèdé to run away from Sékésùá." 
25. (a) Òkó tè sì kè jè è máhé j̀ mì. Òkó wake.AOR up move from 3SG.OBJ.POSS sleep DEF inside "Òkó woke up."

(b) Ngmlàá à há Òkój tè sì kè jè è Noise DEF make.AOR Okoj wake up move from $3 S_{j}$.OBJ.POSS

máhé j̀ mì. sleep DEF inside

"The noise caused Oko to wake up from his sleep."

In examples (24a) Dèdé is the subject of the predicate, mà fo "run". The intransitive sentence in (24a) though declarative, does not express any causative meaning. Thus, it has not pointed out any cause of the action of mà fo "run" undergone by the subject, Dèdé in the syntax.

Example (24b) however, has two clauses. A cause clause, (i) tsjólj̀ o' há "the teacher make" and the result clause, (ii) Dèdé mà fo ké jè Sékésùa "Dèdé run away from Sékésùá". Tsjojl’̀ o' is the subject and actor of the predicate, há and Dèdé is the subject-Undergoer of mà fo "run race" expressed in the second clause of result in (ii). The verb phrase mà fo designates a change of position initiated by the subjectagent, tsjól’ J'. This sentence expresses two actions in a process. Firstly, the object "run" mà fo from a place, Sékésùa and then "moved away" kè jè "move from" to a second position not expressed by the syntax. Sékésùa is a locative noun that indicates the location of the object at $\left(t_{1}\right)$. This verb of motion in (24b) implies volition, energy exertion and control. Change of position indicated in (24a) has not expressed any causer but (24b) falls in the domain of direct causation.

Sentence (25a), just as (24a), is a simple declarative one that has the phrasal verb tè sì "wake up" which designates a change of position. On the other hand, (25b) is bi-clausal, a cause clause, (i) ngmlàa à há "the noise cause" and a result clause, (ii) Òkó tè sì ké jè è $e_{j}$ máhé j̀ mì an expressed causer ngmlàá à "the noise" as the subject of the sentence. Oेkó ${ }_{j}$ is the patient of cause of há and the subject of the result clause. The verb phrase, tè sì k̇ं jè "woke up from" expresses two actions involved in a process. Firstly, the object "woke up" tè si from a position of lying and then "moved from" kغ่ jè, máhé $j$ mi "from sleep" the second position. Máhé $j$ mì is a postpositional phrase denoting the location of object at $\left(\mathrm{t}_{1}\right)$. Ngmlàa $a$ à in the cause clause of $(i)$, is responsible for the change in the position express by tè sì kí jè "woke up, moved from". The result clause in (ii) is the sentential complement of há. Constructions (26a-27b) give us examples of specified new locations of the objects.

26. Àdú há né dj́kità ko jè Akosombo ba tsá Àdú make COMP doctor INDEF from Akosombo come heal

è huno j̀.

3SG.POSS husband DEF

Àdú made a doctor move from Akosombo to heal her husband 
"Àdú caused a doctor to move from Akosombo to heal her husband."

(Asante 1972, p.33)

27. (a) Ehìmó há Nàt ̇̀ tlòó mádàá kè jè Òbényèmí Ehìmó make Nàtż carry plantain move from Òbényżmí

kغ̀ yā Mãnyàkpōngúno.

move to Mãnyàkpōngún

"Ehìmó made Nàtż carried plantain from Òbényżmí to Mãnyàkpōngúno."

(b) Akrobettoe mane kénámí kè jè Asèsèwá yā há Tèż ngè Àdàá. Akrobettoe send fried fish move from Asċsżwá go give Tè丶 at Àdàá "Akrobbettoe sent some fried fish from Asèsèwa to Teye at Ada."

As in (25), example (26) has two clauses, a cause clause and a result clause. Àdú is the subject and the initiator of the discontinuous VP jè... ba tsá "leave...come heal" in the embedded clause of result. The verb phrase of the embedded clause, jè... ba tsá entails movement from one location to another location, that is, from Akosombo to an unspecified destination. Dokità ko "a doctor", is the subject of the second clause and the entity that Àdú has caused to relocate. $\grave{E}$ huno $j$ "her husband" is the object of tsá "heal", the new state of the object-patient, and the result of há "make", while Akosombo is the adverb of place. This implies that, Àdú huno $j$ "Adu's husband" would not have been healed at that particular time $\left(t_{2}\right)$ if the intermediary subject, dokità ko "a doctor" has not at an earlier time $\left(\mathrm{t}_{1}\right)$ moved from the said location, Akosombo to the new location (not specified in the syntax) to treat him.

We observe that examples (27a-b) entail movement of the direct objects mádàá "plantain" in (27a) and kénámí "fried fish" in (27b) from one location to the other. In (27a), the direct object, mádàa "plantain" changes location from Òbényغ̇mí, the original base to a new location, Mãnyàkpōngúno as a result of Nàté carrying it from its original location at an earlier time one $\left(\mathrm{t}_{1}\right)$. Similarly, kénámí "fried fish"; the direct object of construction (27b) is relocated from Asغ̇sغ̇wá to Àdàá, the new location.

\section{Conclusion}

This paper explored the formation of locative constructions in four categories in Dangme; the use of the postpositional class, nouns that function to indicate location and direction to places, positional verbs and verbs of change of location that occur with postpositions and adverbs of location in locative constructions in Dangme. The data showed that postpositions and locative nouns mainly express location in Dangme.

The paper revealed that locative constructions in Dangme can take the form of postpositions which are made up of an NP and locative morphemes: $m i$ "inside", se "back", no/ hiowe "top", kpcti "middle", he "side", nya "edge of, tue "edge", sisi "down"; and locative nouns such as zùgbá "ground", híć o "here", 'lējé o "there", 
bōká "east", àné "west", wò mì b/j" "south" and yìtí màjè "north". The data have shown that bōká "east". àné "west". wò mì blö "south" and yití màjè "north" can be used to mark cardinal relations in locative constructions as exemplified in (6). In

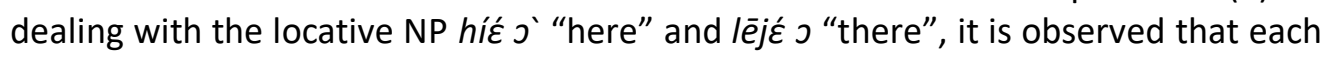
of these NPs can occur with adverb of time as an object of a locative construction as in (4a-4b) and (5a-5b).

In dealing with verbs, it has been shown that in Dangme, there are quite a number of locative predicates used to express causation. They specify the positions or locations assumed by entities. Some of these verbs could however, refer to a number of postures such as sitting, hií sì, standing dàá sì, lying, hwoว sì, hanging, leaning against something kpásà sì, kneeling, kplãã sí, squatting, soว sí that the object may have assumed. These posture verbs signal the relationship between the objects and the ground which is expressed in Dangme by si "down". It is to be noted that in Dangme, a locative morpheme or phrase can co-occur with a positional verb in a construction to express the position of an animate or an inanimate entity at a location. Positional or locative causative verbs indicate re-location of the object in a sentence. In other words, they are characterised by motion.

It is also observed that the verbs of change of location: $k \dot{\varepsilon} f \dot{j}$ "put", wò "put" tsì nyà "detain" are used to indicate a re-location of the object in a sentence. Each of these transitive verbs indicates various positions assumed by the object of the clause. The said positions are complemented by postpositions such as zùgbá "on the ground", mwo' mì "into prison cell", nj̀ "on", ngé tsámì hé "at the hospital", gbògbò $j$ hè "by the wall". In the intransitive clauses, the themes assume the subject's positions of their respective clauses because the subject positions are not filled. They result in the change of location in the objects.

In conclusion, the Dangme locative constructions are composed from the basic locative construction, a construction with a set of nouns that function to indicate location and direction to places and verbs of position and verbs of change of location that function in the basic locative constructions to indicate the location of entities. It is to be noted that postposition and locative nouns mainly express location in Dangme. The postposition class can take the form of a word or a phrase. The phrase is made up of an NP and locative morphemes: mi "inside", se "back", no/hiowe "top", kpeti "middle", he "side" nya "edge of, tue "edge" and sisi "down". A locative morpheme or phrase can co-occur with a positional verb in a construction to express the position of an entity at a location. The findings of the paper will add up to the limited literature on the language and to the study of locative constructions universally.

\section{Abbreviations}

$\begin{array}{ll}\text { ADJ } & \text { Adjective } \\ \text { ADV } & \text { Adverb } \\ \text { AOR } & \text { Aorist } \\ \text { CAUSE } & \text { Causative } \\ \text { DEF } & \text { Definite Article } \\ \text { FOC } & \text { Focus }\end{array}$




$\begin{array}{ll}\text { FUT } & \text { Future } \\ \text { HAB } & \text { Habitual } \\ \text { IPFT } & \text { Imperfective } \\ \text { NP } & \text { Noun Phrase } \\ \text { OBJ } & \text { Object } \\ \text { OBLQ } & \text { Oblique } \\ \text { PERF } & \text { Perfective } \\ \text { POSS } & \text { Possessive } \\ \text { PL } & \text { Plural } \\ \text { PROG } & \text { Progressive } \\ \text { PRT } & \text { Particle } \\ \text { QP } & \text { Question Particle } \\ t_{1} & \text { The Time of the Event } \\ t_{2} & \text { After a Given Earlier Time } \\ \text { V } & \text { Verb } \\ \text { VP } & \text { Verb Phrase } \\ x & \text { First Argument/Subject Actor/Instrument at Subject Position } \\ \text { y } & \text { Argument of the Verb/Object Undergoer } \\ z & \text { Intermediary Actor/Causer } \\ 1 S G & \text { First Person Singular } \\ \text { 1PL } & \text { First Person Plural } \\ 2 P L & \text { Second Person Plural } \\ 3 P L & \text { Third Person Plural } \\ 3 S G . O B J & \text { Third Person Singular Object } \\ 3 S G . P O S S & \text { Third Person Singular Object Possessive Pronoun } \\ \text { j/k/i } & \text { Referential Indices }\end{array}$

\section{References}

Aarts, B. (2001). Modern linguistics: English syntax and argumentation $\left(2^{\text {nd }} e d.\right)$. London: Palgrave Publishing Ltd.

Ameka, F. (1995). The linguistic construction of space in Ewe. Cognitive Linguistics, 6(2/3), 139-181.

Ameka, F. K. (1999). Spatial information packaging in Ewe and Likpe: A comparative perspective. Frankfurter Afrikanistische Blatter, 11, 7-34.

Ameka, F. K., De Witte, C., \& Wilkins, D. (1999). Picture series for positional verbs: Eliciting the verbal component in locative descriptions. In Manual for the 1999 Field Season (pp. 48-54). Nijmegen: Max Planck Institute for Psycholinguistics.

Ameka, F. K., \& Levinson, S. C. (2007). Introduction: Typology and semantics of locative predicates: Posturals, positionals and other beast. Linguistics, 45, 847-871.

Ameka, F. K., \& Dakubu, M. K. (Eds.). (2008). Aspect and modality in Kwa Languages (Vol. 100). Amsterdam: John Benjamins Publishing.

Atintono, S. (2013). The semantics and grammar of positional verbs in Gurene: A 
typological perspective (Unpublished Doctoral dissertation). The University of Manchester, United Kingdom.

Boadi, L. A. (1992, April). Locating objects and events in space. Paper presented at the Linguistics Association of Ghana Annual Conference. Legon: University of Ghana.

Bobuafor, M. (2013). A grammar of Tafi. The Netherlands: Lot.

Borneto, C. S. (1996). Liegen and stehen in German: A study in horizontality and verticality. Cognitive linguistics in the redwoods: The expansion of a new paradigm in linguistics, 6, 459-506.

Christaller, J. G. (1888). Die Volta-Sprachen-Gruppe: drei altbekannte und zwei neubekannte Negersprachen vergleichend besprochen.

Dakubu, K. M. E. (1987). The Dangme Language. Accra: Unimax Publishers Limited.

Dakubu, M. E. K., \& Ford, K. C. (1988). The Central-Togo languages. In M. E. K. Dakubu (Ed.), The languages of Ghana (pp. 119-154). London: Routledge. https://doi.org/10.4324/9781315683393

Dorvlo, K. (2008) A Grammar of Logba (Ikpana). (Unpublished Doctoral dissertation). Leiden University, Netherlands.

Grinevald, C. (2006). The expression of static location in a typological perspective. In M. Hickmann, \& S. Robert (Eds.), Space in languages: Linguistic systems and cognitive categories (pp 29-57). Amsterdam/Philadephia: John Benjamins Publishing Company.

Hellwig, B. (2003). The grammatical coding of postural semantics in Goemai (A West Chadic Language of Nigeria). (Unpublished Doctoral dissertation). Max Planck Institut für Psycholinguistik and Katholieke Universiteit, Nijmegen.

Keegan, J. M. (2002). Posture verbs in Mbay. In J. Newman (Ed), The linguistics of sitting, standing, and lying, (pp. 333-58). Amsterdam/Philadelphia: John Benjamins.

Kutscher, S., \& Genç, N. S. (2007). Laz positional verbs: Semantics and use with Inanimate Figures. Linguistics, 45, 1029-1064.

Lemmens, M., \& Perrez, J. (2010). On the use of posture verbs by Frenchspeaking learners of Dutch: A corpus-based study. Cognitive Linguistics, 21(2), 315-347.

Levin, B. (1993). English verb classes and alternations: A preliminary investigation. Chicago: University of Chicago Press.

Levin, B., Hovav, M. R., \& Keyser, S. J. (1995). Unaccusativity: At the syntax lexical semantics interface (Vol. 26). Cambridge, Massachusetts, and London: The MIT Press.

Levinson, S. C. (1992). Primer for the field investigation of spatial description and conception. Pragmatics, 2(1), 5-47.

Levinson, S. C., \& Wilkins, D. P. (2006). The background to the study of the language of space. In S. C. Levinson \& D. P. Wilkins (Eds.). Grammars of Space: Explorations in Cognitive Diversity (pp. 1-23). Cambridge: Cambridge University Press. 
Newman, J. (Ed.) (2002). The Linguistics of sitting, standing and lying. Typological Studies in Language (TSL). Amsterdam/Philadelphia: John Benjamins.

Quirk, R., \& Greenbaum, S. (1973). A university grammar. London: Longman.

Tallerman, M. (2014). Understanding syntax. New York, USA: Routledge.

Talmy, L. (1985). Lexicalization patterns: Semantic structure in lexical forms. In T. Shopen (Eds), Language typology and syntactic description Vol 3, (pp. 57- 149). Cambridge: Cambridge University Press.

Talmy, L. (2000a). Toward a cognitive semantics. Typological and concept structuring. Vol.1. USA: Massachusetts Institute of Technology.

Talmy, L. (2000b). Toward a cognitive semantics. Typological and concept structuring. Vol. 2. USA: Massachusetts Institute of Technology.

Talmy, L. (2007). Lexical typologies. In Shopen, T. (Eds). Language typology and syntactic descriptions, Vol. III: Grammatical categories and the lexicon, (pp 66-69). Cambridge: Cambridge University Press.

Rapp, E. L. (1943). Die Adangbe-Ga-Mundart Von Agotime in Togo, Afrika (Berlin) $2,1$.

Rothmayr, A. (2009). The structure of stative verbs. Amsterdam and Philadelphia: John Benjamins Publishing Company.

Van Valin Jr \& LaPolla, R. (1997). Syntax, structure, meaning and function. Cambridge: Cambridge University Press.

Van Staden, M. (2007). Grounding objects in space and place: Locative constructions in Tidore. Linguistics, 45, 955-982.

Westermann, D., \& Bryan. M.A. (1952). The Languages of West Africa: Handbook of African Languages (Linguistic Surveys of Africa). London: Oxford University Press. 


\section{APPENDIX A}

Pictures in Appendix A represents photos pointing at some locative positions in Dangme discussed in the paper. They are labeled as LOCP.

1. A dog under a tree. (LOCP1)

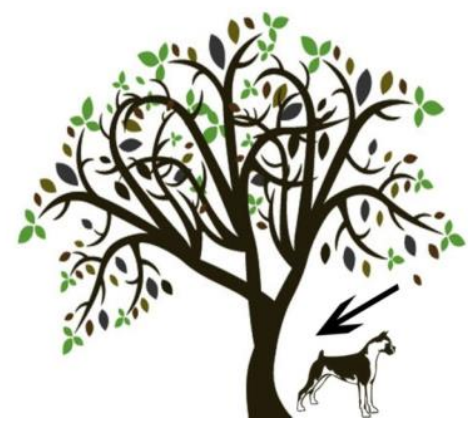

2. Some people eating at an entrance of a door. (LOCP2)

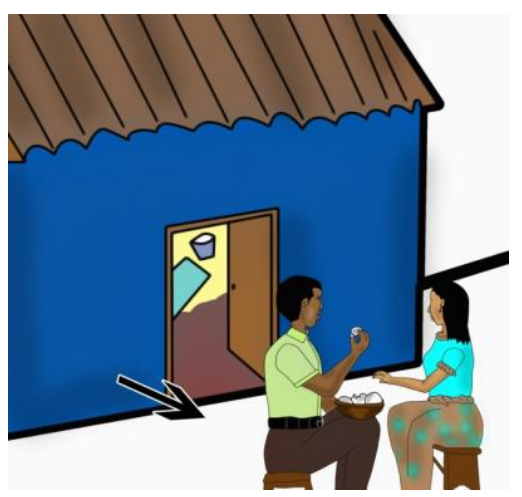

3. A bag in a box.( LOCP3)

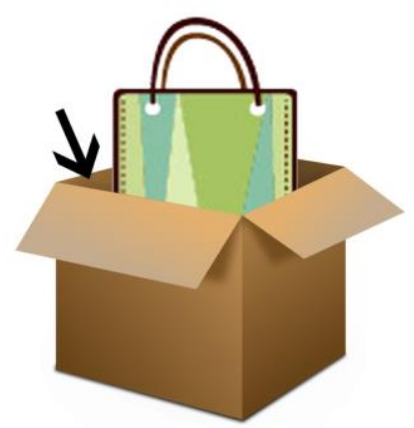

4. A teacher at the river bank.( LOCP4) 


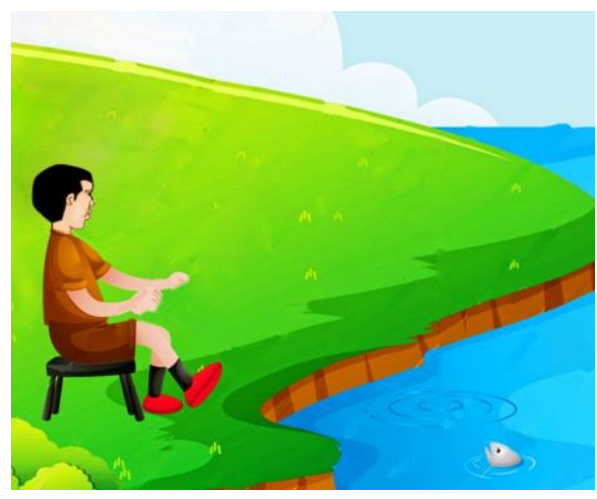

5. A cat on a roof top. (LOCP5)

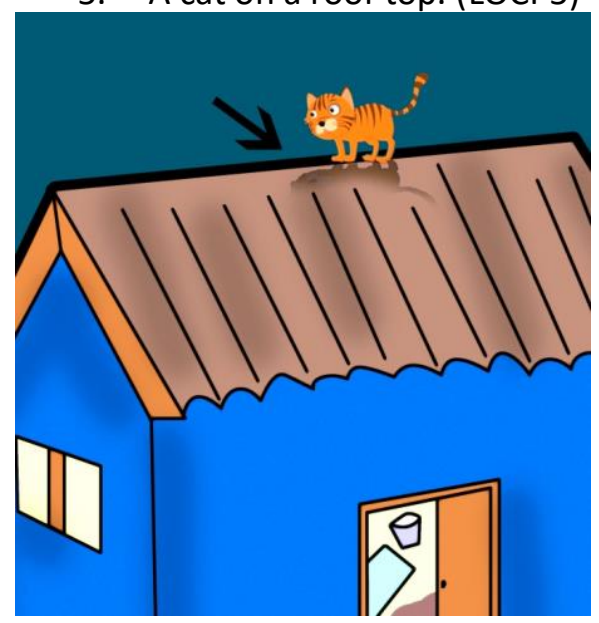

6. A cup on the surface of water.( LOCP6)

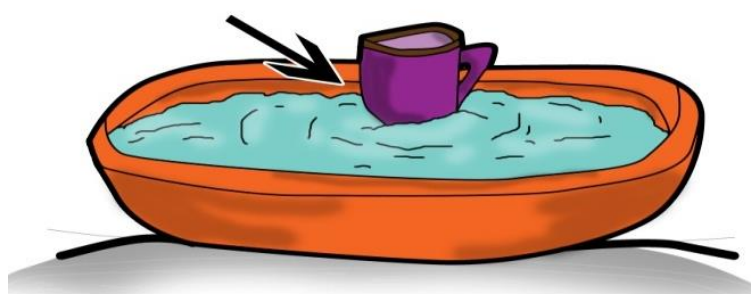

7. A pair of sandals under a table. (LOCP7) 
Issues in Language Studies (Vol 9 No 2, 2020)

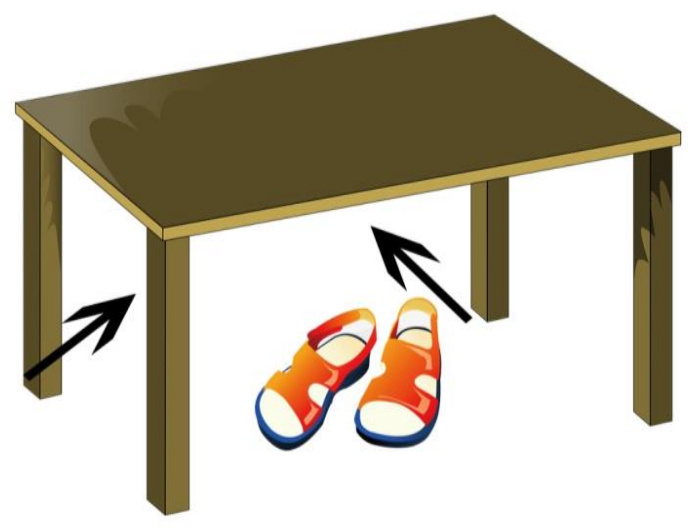

8. A nice car parked in front of a house.( LOCP8)

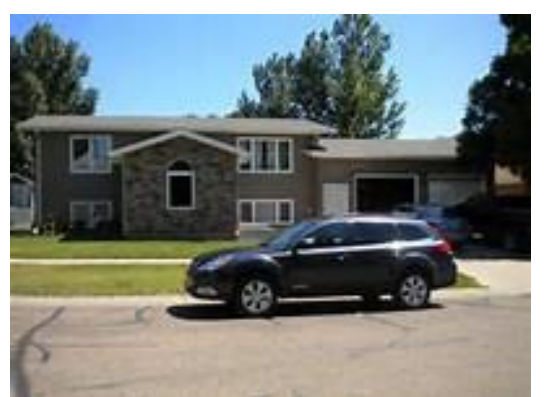

https://www.bing.com/images/search/ 


\section{APPENDIX B}

Pictures under this section represent various positions and postures of entities discussed in Dangme. Each of these photos is prefixed with PPOS...

1. A man sitting on a chair. (PPOS1)

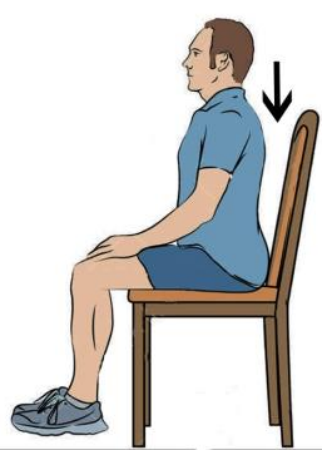

2. A baby lying down on a mat. (PPOS2)

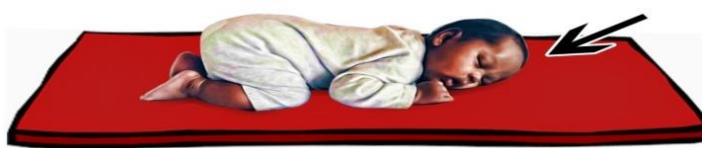

3. Someone at a kneeling position. (PPOS3)

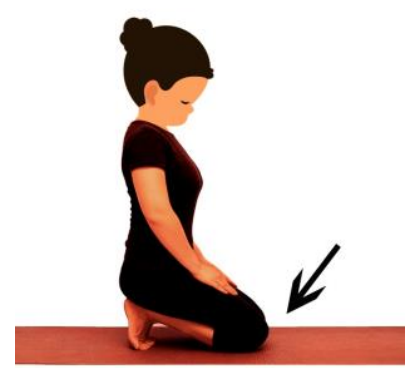

4. A man at a squatting position. (PPOS4)

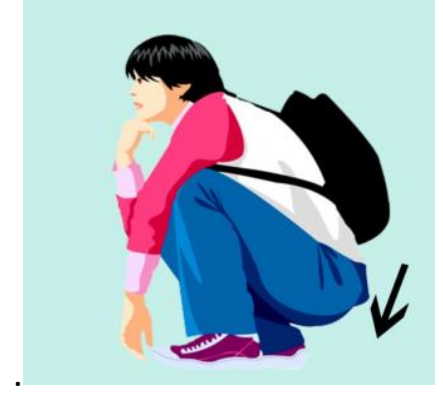

5. A man leaning against a wall. (PPOS5) 


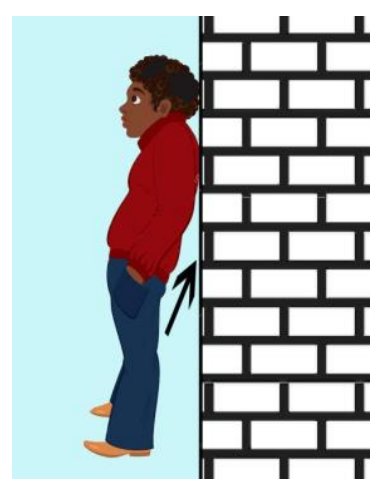

6. A rope hanging on something. (PPOS6)

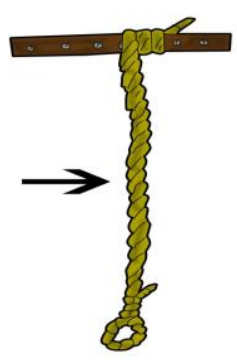

7. A ladder leaning against a wall. (PPOS7)

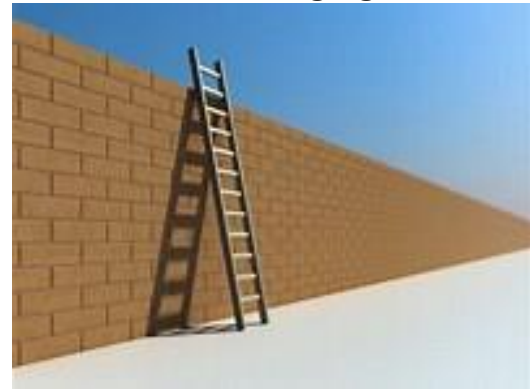

www.clutterfairyhouston.com

8. A lady at a standing position. (PPOS8)

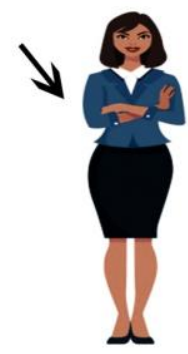

